\title{
Analisis Faktor Resiko Kejadian Abortus di RSUP Dr. M.Djamil Padang
}

\author{
Lili Fajria ${ }^{a}$ \\ Fakultas Keperawatan Universitas Andalas
}

\begin{abstract}
One of the factors leading to high maternal mortality rate and infant mortality rate in Indonesia is the incidence of abortion. This study examines the risk factors what causes abortion incidence in pregnant women at Dr M.Djamil Padang Hospital . Research methods to approach cross-sectional descriptive analytic study . Total population of 125 people and is set as a sample in accordance with the criteria of only 52 respondents with a univariate analysis of the frequency distribution techniques and bivariate analysis with the Chi - Square formula. The results showed the incidence of abortion in $\mathrm{Dr}$. M.Djamil Padang Hospital occurs more frequently in women who had one abortion, namely : $84.6 \%$ ( 44 persons ), while women with the incidence of abortion more than once only $15.4 \%$ ( 8 people). And for occupational factors and factors associated with hemoglobin levels if the incidence of abortion showed a significant result that the work factor and the factor $p=$ $0.000 \mathrm{hb}$ levels $p=0.001$. As for age, parity factor, Medical history factor and distance factors with previous pregnancies showed no significant results. Need an effort to further examine other factors that may contribute to the incidence of abortion in the mother.
\end{abstract}

Key words : abortion incidence, risk factors

Abstrak: Salah satu faktor yang menyebabkan tingginya angka kematian ibu dan angka kematian bayi di Indonesia adalah kejadian abortus. Penelitian ini bertujuan melihat faktor-faktor resiko apa saja yang menyebabkan kejadian abortus pada ibu hamil di RSUP M.Djamil Padang. Metode penelitian deskriptif analitik dengan pendekatan crosssectional study. Jumlah populasi sebanyak 125 orang dan yang ditetapkan sebagai sampel sesuai dengan kriteria hanya 52 responden Analisa univariat dengan tekhnik distribusi frekwensi dan analisa bivariat dengan rumus Chi-Square. Hasil penelitian menujukkan angka kejadian abortus di RSUP Dr. M.Djamil Padang lebih banyak terjadi pada ibu yang mengalami satu kali abortus yakni : 84,6 \% (44 orang) sedangkan ibu yang mengalami kejadian abortus lebih dari satu kali hanya 15,4\% (8 orang ). Dan untuk faktor pekerjaan dan faktor kadar $\mathrm{Hb}$ jika dihubungkan dengan kejadian abortus menunjukkan hasil yang signifikan yakni faktor pekerjaan $\mathrm{p}=0,000$ dan faktor kadar hb nilai $\mathrm{p}=0,001$. Sedangkan faktor umur, Faktor Paritas, Faktor Riwayat penyakit dan Faktor jarak kehamilan dengan yang sebelumnya tidak menunjukkan hasil yang signifikan. Perlu upaya untuk meneliti lebih lanjut faktor-faktor lain yang dapat memberikan kontribusi pada kejadian abortus pada ibu.

Kata Kunci: kejadian abortus, faktor resiko

\section{PENDAHULUAN}

Pelayanan kesehatan termasuk salah satu industri jasa yang perlu mendapatkan perhatian serius baik dari pemerintah maupun dari institusi yang terkait. Salah satu bukti tersebut pemerintah Indonesia dan beberapa negara melakukan penandatanganan deklarasi tahun 2000 melalui perwakilannya menetapkan deklarasi yang disebut sebagai Millenium Declaration yang mengandung 8 tujuan yang harus dicapai sebelum tahun 2015, yakni (1) Menanggulangi kemiskinan, (2) Memenuhi pendidikan dasar untuk semua,
(3) Mendorong kesetaraan jender dan pemberdayaan perempuan, (4) Menurunkan angka kematian balita, (5) Meningkatkan kualitas kesehatan ibu melahirkan, (6) Memerangi HIV/AIDS, malaria dan penyakit menular lain, (7) Menjamin kelestarian fungsi lingkungan hidup, (8) Mengembangkan kemitraan global untuk pembangunan (Depkes, 2010).

Tujuan Pembangunan Millenium atau yang dinamakan dengan Millenium Development Goals (MDGs) pada tanggal 10 September 2005, lima tahun setelah penandatanganan deklarasi Millenium 
mengadakan rapat evaluasi negara-negara yang menandatangani deklarasi tersebut, yang salah satu poin dari program MDGs yakni meningkatkan kualitas kesehatan ibu melahirkan, masih menjadi sorotan karna pencapaian nya belum seperti yang diharapkan, menurut WHO tahun 2010 di seluruh dunia terdapat kematian ibu sebesar 500.000 jiwa per tahun dan kematian bayi khususnya neonatus sebesar 10.000 .000 jiwa per tahun. Kematian maternal dan bayi tersebut terjadi terutama di Negara berkembang sebesar 99\%.( Depkes, 2010).

Sebenarnya kematin ibu dan bayi mempunyai peluang yang sangat besar untuk dihindari dengan meningkatkan kerja sama antara pemerintah, swasta dan badan sosial lainnya,dengan harapan tercapainya pembangunan millenium 2015 (Depkes, 2010).

Di Indonesia tahun 2009 telah diperkirakan 228 orang ibu meninggal dalam tiap 1.000 proses persalinan di Indonesia. Angka kematian ibu saat melahirkan yang telah di targetkan dalam MDGs pada tahun 2015 adala 110, dengan kata lain akselerasi sangat dibutuhkan sebab pencapaian target tesebut masih cukup jauh. Indonesia dianggap belum mampu mengatasi tingginya angka kematian ibu yang 307 per 1.000 kelahiran hidup. Berarti setiap tahunnya ada 13.778 kematian ibu data setiap dua jam ada dua ibu hamil, bersalin, nifas yang meninggal karena berbagai penyebab. Kecenderungan perbandingan pada tahun 1990 yang masih 450 per 1.000 kelahiran hidup, namun target MDGs yang 125 per 1.000 kelahiran hidup terasa sangat berat untuk dicapai tanpa upaya percepatan (Kompas, 2 Desember 2009).Salah satu faktor penyebab tingginya angka kematian pada ibu adalah kasus abortus.

Abortus adalah ancaman atau pengeluaran hasil konsepsi pada usia kehamilan kurang dari 20 minggu atau berat janin kirang dari 500 gram (kapital selekta, 2001 : 260). Kejadian abortus sulit diketahui karena sebagian besar tidak dilaporkan dan banyak dilakukan atas permintaan. Keguguran spontan diperkirakan sebesar $10 \%$ sempai $15 \%$ (Manuaba, 1998 : 214).

Ada beberapa faktor yang merupakan penyebab terjadinya abortus yaitu faktor paritas $25 \%$, umur $12-26 \%$ dan riwayat abortus $30-45 \%$ yang mempunyai pengaruh besar. Resiko abortus semakin tinggi dengan bertambahnya paritas, semakin bertambahnya umur ibu dan ayah (Cunningham, 2005). Ada juga faktor lain yang berpengaruh yaitu riwayat abortus merupakan predisposisi terjadinya abortus berulang. Kemungkinan terjadinya abortus berulang pada seorang wanita yang mengalami abortus tiga kali atau lebih adalah 83,6 \% (Wiknjosastro, 2000). Penelitian Suarni tahun 2006 di Makasar juga mengatakan selain faktor umur dan paritas kadar $\mathrm{Hb}$ ibu juga menjadi penyebab tingginya angka abortus pada ibu.

Frekuensi abortus yang dikenali secara klinis bertambah dari $12 \%$ pada wanita yang berusia kurang dari 20 tahun, menjadi $26 \%$ pada wanita berumur diatas 40 tahun. Insiden abortus bertambah jika kandungan wanita tersebut melebihi umur 3 bulan. Kejadian abortus diduga mempunyai efek terhadap kehamilan berikutnya, baik pada timbulnya penyulit kehamilan maupun pada hasil kehamilan itu sendiri. Wanita dengan riwayat abortus mempunyai resiko yang lebih tinggi untuk terjadinya persalinan Prematur, Abortus Berulang, Berat Badan Lahir Rendah (BBLR) (Cunningham, 2005). Selain beberapa faktor diatas, penyakit ibu seperti pneumonia, typhus abdominalis, pielonefritis, malaria dan lain-lain dapat menyebabkan abortus, kelainan pertumbuhan hasil konsepsi, kelainan pada plasenta, kelainan traktus genitalis. Begitu pula dengan penyakit-penyakit infeksi lain juga memperbesar peluang terjadinya 
abortus (Prawirohardjo dan Wiknjosastro, 2007 : 301). Kondisi ibu yang bekerja juga dapat menjadi faktor predisposisi kejadian abortus pada ibu.

Dilihat dari Indonesia tahun 2010 terdapat Estimasi Nasional yang menyatakan setiap tahun terjadi 2 juta kasus abortus di Indonesia. Ini artinya terdapat 43 kasus abortus per 1000 kelahiran hidup. Menurut hasil sensus penduduk tahun 2010 terdapat 53.783.717 perempuan usia 15-49 tahun 37 kasus per tahun per 1000 perempuan 15-49 tahun (berdasarkan Crude Birth Rate (CBR) sebesar 23 per 1000 kelahiran hidup. Di Sumatera Barat didapatkan angka kematian bayi pada 2009 sebesar 58 per 1.000 kelahiran hidup dan pada tahun 2010 sebesar 34 per 1.000 kelahiran hidup (Dinkes Sumbar, 2010). Dari data RSUP Dr. M. Djamil Padang pada tahun 2011, dilaporkan 113 kasus abortus yang dilakukan tindakan di RSUP M.Djamil Padang, sedangkan Data rekam medis untuk kasus abortus tahun 2012 terjadi peningkatan yakni 125 kasus abortus, ( MR M.Djamil Padang, 2013).

Berdasarkan fenomena diatas tingginya angka kematian pada ibu yang salah satu faktor penyebanya adalah kasus abortus dan banyaknya faktor penyebab abortus, maka penulis tertarik untuk melakukan Analisis Faktor Resiko Kejadian Abortus di RSUP Dr. Djamil Padang tahun 2013.

\section{METODE}

\section{Desain Penelitian}

Penelitian ini bersifat deskriptif analitik dengan rancangan penelitian cross sectional yaitu penelitian survey analitik yang menyangkut bagaimana faktor resiko dipelajari dengan menggunakan pendekatan retrospektiv (Notoadmojo, $2005: 150$ ) untuk menilai faktor-faktor yang berhubungan dengan kejadian abortus.

\section{Tempat dan Waktu Penelitian}

Penelitian dilakukan di RSUP Dr. M.Djamil Padang pada bulan Juli s/d September 2013 dengan melihat catatan medical record RSUP Dr.M.Djamil Padang

\section{Populasi dan Sampel \\ Populasi}

Populasi kasus penelitian ini adalah keseluruhan laporan kasus Abortus dari bangsal kebidanan pada tahun 2012 berjumlah 125 kasus.

\section{Sampel}

Pengambilan sampel diambil secara total sampling yaitu seluruh populasi dijadikan sampel dalam penelitian ini.jadi sampel dalam penelitian ini adalah 125 kasus dengan kriteria semua cacatan yang dibutuhkan serta alamat jelas( no. Telp ) terdapat di dalam catatan rekam medik RSUP Dr. M.Djamil Padang

\section{Teknik Pengumpulan Data}

Teknik pengumpulan data yang digunakan yaitu retrospektiv. Pengolahan data dilakukan setelah pengumpulan data dilaksanakan, data yang dikumpulkan dalam penelitian ini berasal dari data sukunder melalui catatan Rekam Medik keperawatan di RSUP Dr. Djamil Padang dengan menggunakan cheklis. Data sukunder adalah data penunjang yang telah ada untuk dilakukan penelitian .

\section{Pengolahan Data dan Analisa Data}

Pengolahan data dilakukan setelah pengumpulan data, dengan maksud agar data yang di kumpulkan memiliki sifat yang jelas. Adapun langkah-langkah dalam pengolahan data, yaitu : editing, coding, proccesing dan entery serta cleaning. Kemudian dilakukan analisa data secara univariat dengan standar sebagai berikut :

a) Pendidikan Ibu Pendidikan formal yang ditempuh oleh ibu sebelumnya

$$
\text { - } \quad \text { Tinggi : SMA - PT }
$$


- Rendah: Tidak sekolah/SD - SMP

b) Variabel paritas ibu

Paritas ibu dilihat dengan menggunakan cheklis, apabila terdapat paritas maka diberi tanda cheklis, dengan kategori :

- ya: berjumlah $\geq 3$ orang anak

- Tidak : berjumlah $<3$ orang anak

c) Variabel umur ibu

Umur ibu dilihat dengan menggunakan cheklis, apabila terdapat umur ibu maka diberi tanda cheklis, dengan kategori :

- Ya: $<20$ tahun $\geq 35$ tahun

- Tidak : $\geq 20$ - 35 tahun

d) Variabel Pekerjaan

Pekerjaan ibu dilihat dengan menggunakan cheklis, dengan kategori :

- Bekerja

- Tidak bekerja

e) Penyakit yang diderita ibu

Penyakit yang diderita ibu dilihat dengan menggunakan cheklis dengan kategori :

- Ad

- Tidak ada

f) Riwayat $\mathrm{Kb}$

Alat kontrasepsi yang pernah digunakan oleh ibu :

- Ya : apabila ibu pernah menggunakan salah satu alat $\mathrm{Kb}$

- Tidak : apabila ibu tidak pernah menggunakan salah satu alat $\mathrm{Kb}$.

g) Jarak kehamilan sebelumnya

Rentang waktu yang dilalui ibu pada kehamilan sebelumnya

- Ya : apabila jarak kelahiran sebelumnya kurang dari 2 tahun

- Tidak : apabila jarak kelahiran sebelumnya lebih dan sama dengan 2 tahun.

h) Kadar $\mathrm{Hb}$ ibu

Kadar $\mathrm{Hb}$ ibu lihat dengan menggunakan cheklis dengan kategori :

- Normal: diatas $11 \mathrm{gr} \% / \mathrm{dl}$

- Rendah: dibawah 11 gr\%/dl

\section{Analisa Bivariat}

Untuk melihat hubungan antara variabel independen dan dependen dilakukan perhitungan dengan rumus chisquare dengan derajat kemaknaan signifikan $\mathrm{p}=0,05$.

Dengan rumus :

$$
X^{2}=\sum \frac{(0-E)^{2}}{E}
$$

Keterangan :

$$
\begin{array}{ll}
X^{2} & : \text { Chi }- \text { square } \\
& =\text { : Frekuensi harapan }
\end{array}
$$

$\sum \quad:$ Jumlah total

1 : Frekuensi observasi

Untuk melihat hasil kemaknaan

perhitungan adalah sebagai berikut :

a. Bila $X^{2}$ hitung $\geq X^{2}$ tabel maka Ha diterima dan terdapat hubungan yang bermakna antara faktor-faktor yang berhubungan dengan kejadian abortus $(\alpha=0,05)$.

b. Bila $X^{2}$ hitung $<X^{2}$ tabel maka Ha ditolak dan tidak terdapat hubungan yang bermakna antara faktor-faktor yang berhubungan dengan kejadian abortus $(\alpha=0,05)$.

\section{HASIL DAN PEMBAHASAN}

Penelitian telah dilaksanakan di RSUP DR. M.Djamil Padang dari bulan juli s/d bulan Oktober 2013. Pelaksanaan penelitian memerlukan waktu selama \pm 30 hari dengan jumlah sampel awal sebanyak 125 orang. Namun setelah dilihat data keseluruhan sampel yang ada hanya 52 responden yang didapatkan sesuai dengan kriteria yakni semua data yang dibutuhkan tersedia dan lengkap termasuk alamat dan usia hamil saat mengalami abortus. Sedangkan 14 responden tidak ditemui status klien di MR RSUP Dr. M.Djamil Padang, dan sisanya merupakan status yang tidak lengkap termasuk 3 status bukan merupakan kasus kebidanan tapi internist. 
Dari 52 responden yang ada setelah dilakukan pencatatan medikal record tentang identitas, umur, pendidikan, pekerjaan, usia gestasi , riwayat penyakit yang diderita ibu serta kadar $\mathrm{Hb}$ ibu, hasil untuk gambaran karakteristik respon yakni:

a. Usia kehamilan

Tabel 4.1. Distribusi Frekwensi Usia Responden Saat Terjadi abortus.

\begin{tabular}{|c|c|c|}
\hline Usia kehamilan & Frekwensi & $\%$ \\
\hline$<8 \mathrm{mgg}$ & 8 & 15 \\
\hline $8 \mathrm{mgg}-10 \mathrm{mgg}$ & 20 & 38 \\
\hline$>10 \mathrm{mgg}$ & 24 & 46 \\
\hline Jumlah & 52 & 100 \\
\hline
\end{tabular}

Dari Tabel 4.1 diatas terlihat bahwa usia kehamilan ibu saat terjadi abortus lebih banyak pada kehamilan lebih dari 10 minggu yakni : $46 \%$. ( 24 orang )

b. Pendidikan

Tabel 4.2 . Distribusi Frekwensi responden berdasarkan tingkat Pendidikan

\begin{tabular}{|c|c|c|}
\hline Pendidikan & Frekwensi & $\%$ \\
\hline Rendah & 10 & 19,2 \\
\hline Tinggi & 42 & 80.8 \\
\hline Jumlah & 52 & 100 \\
\hline
\end{tabular}

Dari Tabel 4.2 diatas terlihat tingkat pendidikan responden lebih banyak berada pada pendidikan tinggi ( SMA keatas) yakni : $80.1 \%$. ( 42 orang )

c. Riwayat Keluarga berencana

Tabel 4.3 Distribusi Frekwensi Responden berdasarkan riwayat penggunakan $\mathrm{Kb}$

\begin{tabular}{|c|c|c|}
\hline $\begin{array}{l}\text { Riwayat Keluarga } \\
\text { berencana }\end{array}$ & Frekwensi & $\%$ \\
\hline Ada & 15 & 28.8 \\
\hline Tidak ada & 37 & 71.2 \\
\hline Jumlah & 52 & 100 \\
\hline
\end{tabular}

Dari Tabel 4.3 diatas terlihat responden hanya sebagian kecil responden yang menggunakan alat Kontrasepsi, yakni : $28.1 \%$ ( 15 orang )

\section{HASIL DAN PEMBAHASAN}

1. Analisa Univariat

a. Paritas

Tabel 4.4 Distribusi Frekwensi responden berdasarkan Paritas ( jumlah anak )

\begin{tabular}{|c|c|c|}
\hline Paritas & Frekwensi & $\%$ \\
\hline$\geq 3$ & 31 & 59.6 \\
\hline$<3$ & 21 & 40,4 \\
\hline Jumlah & 52 & 100 \\
\hline
\end{tabular}


Dari Tabel 4.4 terlihat jumlah anak ( paritas ) lebih banyak responden memiliki jumlah anak lebih dari 3 yakni : 59,6\% ( 31 Orang )

b. Umur Ibu

Tabel 4.5 Distribusi Frekwensi responden berdasarkan umur ibu saat kedaian abortus.

\begin{tabular}{|c|c|c|}
\hline Umur Ibu & Frekwensi & $\%$ \\
\hline Penyebab & 22 & 42.3 \\
\hline Tidak penyebab & 30 & 57.7 \\
\hline Jumlah & 52 & 100 \\
\hline
\end{tabular}

Dari Tabel 4.5 terlihat sebagian responden jika dilihat dari sisi umur yang menyebabkan abortus terdapat $57.7 \%$ ( 30 orang )

c. Pekerjaan

Tabel 4.6. Distribusi Frekwensi responden berdasarkan Pekerjaan

\begin{tabular}{|c|c|c|}
\hline Pekerjaan & Frekwensi & $\%$ \\
\hline Bekerja & 8 & 15.3 \\
\hline Tidak Bekerja & 44 & 84.6 \\
\hline Jumlah & 52 & 100 \\
\hline
\end{tabular}

Dari Tabel 4.6 terlihat pada umumnya responden tidak bekerja yakni 84,6 \% (44 orang)

d. Riwayat Penyakit yang diderita ibu

Tabel 4.7 .Distribusi Frekwensi Responden Berdasarkan Riwayat Penyakit Yang diderita saat kejadian abortus

\begin{tabular}{|c|c|c|}
\hline Riwayat penyakit & Frekwensi & $\%$ \\
\hline Ada & 1 & 0.02 \\
\hline Tidak ada & 51 & 98,08 \\
\hline Jumlah & 52 & 100 \\
\hline
\end{tabular}

Dari Tabel 4.7 terlihat sebagian besar responden tidak ada menderita penyakit pada waktu kejadian abortus.

e. Jarak

Tabel 4.8 Distribusi Frekwensi Responden berdasarkan Jarak dengan Kehamilan sebelumnya.

\begin{tabular}{|c|c|c|}
\hline Jarak & Frekwensi & $\%$ \\
\hline Beresiko & 22 & 42.3 \\
\hline Tidak Beresiko & 30 & 57.7 \\
\hline Jumlah & 52 & 100 \\
\hline
\end{tabular}

Dari Tabel 4.8 terlihat sebagian responden jarak kehamilannya tidak beresiko dalam penyebab abortus yakni $57.7 \%$ ( 30 orang ) 
f. Kadar $\mathrm{Hb}$

Tabel 4.9. Distribusi Frekwensi Responden Berdasarkan Kadar Haemoglobin

\begin{tabular}{|c|c|c|}
\hline Kadar $\mathrm{Hb}$ & Frekwensi & $\%$ \\
\hline Rendah & 11 & 21,2 \\
\hline Normal & 41 & 78,8 \\
\hline Jumlah & 52 & 100 \\
\hline
\end{tabular}

Dari Tabel 4.9 terlihat sebagian besar responden memiliki Kadar Hb Normal Yakni : 78.8 $\%$ ( 41 orang )

g. Kejadian abortus

Tabel 4.10 Distribusi Frekwensi Responden Berdasarkan Kejadian Abortus

\begin{tabular}{|c|c|c|}
\hline Kejadian Abortus & Frekwensi & $\%$ \\
\hline Lebih $1 \mathrm{x}$ & 8 & 15,4 \\
\hline Mengalami $1 \mathrm{x}$ & 44 & 84,6 \\
\hline Jumlah & 52 & 100 \\
\hline
\end{tabular}

Dari Tabel 4.10 terlihat responden yang mengalami kejadian abortus lebih dari 1 kali hanya $15.4 \%$ ( 8 orang )

\section{Analisa Bivariat}

Tabel 4.11 Hubungan Paritas dengan Kejadian Abortus

\begin{tabular}{|c|c|c|c|c|c|c|c|c|}
\hline \multirow{3}{*}{ No } & \multirow{3}{*}{ Paritas } & \multicolumn{4}{|c|}{ Kejadian abortus } & \multirow{2}{*}{\multicolumn{2}{|c|}{ Jumlah }} & \multirow{3}{*}{$P$ value } \\
\hline & & \multicolumn{2}{|c|}{$\begin{array}{l}\text { Mengalami abortus } \\
\text { lebih } 1 \text { kali }\end{array}$} & \multicolumn{2}{|c|}{$\begin{array}{l}\text { Mengalami } \\
\text { abotus } 1 \text { kali }\end{array}$} & & & \\
\hline & & $\mathrm{F}$ & $\%$ & $\mathrm{~F}$ & $\%$ & $\mathrm{~F}$ & $\%$ & \\
\hline 1 & Penyebab & 4 & 12,9 & 27 & 87,1 & 31 & 100,0 & \multirow{3}{*}{0,700} \\
\hline \multirow[t]{2}{*}{2} & $\begin{array}{c}\text { Tidak } \\
\text { Penyebab }\end{array}$ & 4 & 19,0 & 17 & 81,0 & 21 & 100,0 & \\
\hline & Jumlah & 8 & 15,4 & 44 & 84,6 & 52 & 100 & \\
\hline
\end{tabular}

Dari Tabel 4.11 dapat dilihat tidak ada hubungan paritas dengan kejadian abortus dimana nilap $\mathrm{p}=0.700>0,05$.

Tabel 4.12. Hubungan antara umur dengan kejadian Abortus

\begin{tabular}{|c|c|c|c|c|c|c|c|c|}
\hline \multirow{3}{*}{ No } & \multirow{3}{*}{ Umur } & \multicolumn{4}{|c|}{ Kejadian Abortus } & \multirow{2}{*}{\multicolumn{2}{|c|}{ Jumlah }} & \multirow{3}{*}{$P$ value } \\
\hline & & \multicolumn{2}{|c|}{$\begin{array}{c}\text { Mengalami lebih } 1 \\
\text { kali }\end{array}$} & \multicolumn{2}{|c|}{$\begin{array}{l}\text { Mengalami } 1 \\
\text { kali }\end{array}$} & & & \\
\hline & & $\mathrm{F}$ & $\%$ & $\mathrm{~F}$ & $\%$ & $\mathrm{~F}$ & $\%$ & \\
\hline 1 & Penyebab & 3 & 13,6 & 19 & 86,4 & 22 & 100,0 & \multirow{3}{*}{1,000} \\
\hline 2 & $\begin{array}{c}\text { Tidak } \\
\text { Penyebab }\end{array}$ & 5 & 16,7 & 25 & 83,3 & 30 & 100.0 & \\
\hline & Jumlah & 8 & 15,4 & 44 & 45,5 & 33 & 100 & \\
\hline
\end{tabular}


Dari Tabel 4.12 diatas terlihat tidak ada hubungan faktor umur dengan kejadian abortus dimana $\mathrm{p}=1,000>0,05$

Tabel 4.13. Hubungan Faktor Pekerjaan dengan Kejadian Abortus

\begin{tabular}{|c|c|c|c|c|c|c|c|c|}
\hline \multirow{3}{*}{ No } & \multirow{3}{*}{ Pekerjaan } & \multicolumn{4}{|c|}{ Kejadian Abortus } & \multirow{2}{*}{\multicolumn{2}{|c|}{ Jumlah }} & \multirow{3}{*}{$P$ value } \\
\hline & & \multicolumn{2}{|c|}{$\begin{array}{l}\text { Mengalami } \\
\text { abortus lebih } 1 \\
\text { kali }\end{array}$} & \multicolumn{2}{|c|}{$\begin{array}{l}\text { Mengalami } \\
\text { Abortus } 1 \text { kali }\end{array}$} & & & \\
\hline & & $\mathrm{F}$ & $\%$ & $\mathrm{~F}$ & $\%$ & $\mathrm{~F}$ & $\%$ & \\
\hline 1 & Bekerja & 6 & 75,0 & 2 & 25,0 & 8 & 100.0 & \multirow{3}{*}{0,000} \\
\hline \multirow[t]{2}{*}{2} & Tidak Bekerja & 2 & 4,5 & 42 & 95,5 & 44 & 100.0 & \\
\hline & Jumlah & 8 & 54,5 & 44 & 45,5 & 52 & 100 & \\
\hline
\end{tabular}

Dari Tabel 4.13 diatas dapat dilihat ada hubungan pekerjaan dengan kejadian abortus dimana $\mathrm{p}=0,000<0,05$.

Tabel 4.14. Hubungan Riwayat Penyakit Ibu dengan Kejadian Abortus

\begin{tabular}{|c|c|c|c|c|c|c|c|c|}
\hline \multirow{3}{*}{ No } & \multirow{3}{*}{ Riwayat penyakit } & \multicolumn{4}{|c|}{ Kejadian Abortus } & \multirow{2}{*}{\multicolumn{2}{|c|}{ Jumlah }} & \multirow{3}{*}{$P$ value } \\
\hline & & \multicolumn{2}{|c|}{$\begin{array}{c}\text { Mengalami Abortus } \\
\text { lebih } 1 \text { kali }\end{array}$} & \multicolumn{2}{|c|}{$\begin{array}{c}\text { Mengalami } \\
\text { Abortus } 1 \text { kali }\end{array}$} & & & \\
\hline & & $\mathrm{F}$ & $\%$ & $\mathrm{~F}$ & $\%$ & $\mathrm{~F}$ & $\%$ & \\
\hline 1 & $\begin{array}{l}\text { Pernah menderita } \\
\text { suatu penyakit }\end{array}$ & 0 & 0,0 & 1 & 100,0 & 1 & 100,0 & \\
\hline 2 & $\begin{array}{c}\text { Tidak Pernah } \\
\text { Menderita Suatu } \\
\text { penyakit }\end{array}$ & 8 & 15,7 & 43 & 84,3 & 51 & 63,6 & 1,000 \\
\hline & Jumlah & 18 & 15,4 & 44 & 84,6 & 52 & 100 & \\
\hline
\end{tabular}

Dari Tabel 4.14 diatas terlihat tidak ada hubungan riwayat penyakit yang diderita ibu dengan kejadian Abortus dimana $\mathrm{p}=1,000>0,05$

Tabel 4-15. Hubungan Jarak Kelahiran Sebelumnya dengan Kejadian Abortus

\begin{tabular}{|l|l|l|l|l|l|l|l|l|}
\hline \multirow{2}{*}{ No } & \multirow{2}{*}{$\begin{array}{l}\text { Jarak } \\
\text { Kelahiran } \\
\text { Sebelumnya }\end{array}$} & \multicolumn{2}{|l|}{ Kejadian Abortus } & \multicolumn{2}{l|}{\begin{tabular}{l}
\multirow{2}{*}{ Mengalami Abortus } \\
lebih 1 kali
\end{tabular}} & \multicolumn{2}{l|}{$\begin{array}{l}\text { Mengalami } \\
\text { Abortus 1 kali }\end{array}$} & \multicolumn{2}{l|}{ Pumlah } & \\
\cline { 2 - 8 } & & F & $\%$ & F & $\%$ & F & $\%$ & \\
\hline 1 & Beresiko & 5 & 22,7 & 17 & 77,3 & 22 & 100,0 & \multirow{2}{*}{0,260} \\
\hline 2 & $\begin{array}{l}\text { Tidak } \\
\text { Beresiko }\end{array}$ & 3 & 10,0 & 27 & 90,0 & 30 & 100,0 & \\
\hline & Jumlah & 8 & 15,4 & 44 & 45,5 & 52 & 100 & \\
\hline
\end{tabular}

Dari Tabel 4.15 terlihat tidak ada hubungan antara jarak kelariran sebelumnya dengan kejadian abortus, dimana $\mathrm{p}=0,260>0,05$ 


\section{a. Hubungan Kadar Hb dengan Kejadian Abortus}

Tabel 4.16. Hubungan AntaraKadar Hb ibu dengan Kejadian Abortus

\begin{tabular}{|c|c|c|c|c|c|c|c|c|}
\hline \multirow{3}{*}{ No } & \multirow{3}{*}{ Kadar $\mathrm{Hb}$} & \multicolumn{4}{|c|}{ Kejadian Abortus } & \multirow{2}{*}{\multicolumn{2}{|c|}{ Jumlah }} & \multirow{3}{*}{ Pvalue } \\
\hline & & \multicolumn{2}{|c|}{ Ada kesulitan } & \multicolumn{2}{|c|}{$\begin{array}{l}\text { Tidak ada } \\
\text { kesulitan }\end{array}$} & & & \\
\hline & & $\mathrm{F}$ & $\%$ & $\mathrm{~F}$ & $\%$ & $\mathrm{~F}$ & $\%$ & \\
\hline 1 & Rendah & 6 & 54,4 & 5 & 45,5 & 11 & 100,0 & \multirow{3}{*}{0,001} \\
\hline 2 & Normal & 2 & 4,9 & 39 & 95,1 & 41 & 100,0 & \\
\hline & Jumlah & 8 & 54,5 & 44 & 45,5 & 52 & 100 & \\
\hline
\end{tabular}

Dari Tabel 4.16 terlihat ada hubungan antara kadar $\mathrm{Hb}$ dengan Kejadian abortus dimana $\mathrm{p}=0.001<0,05$.

Hasil penelitian yang telah dilakukan pada ibu yang mengalami abortus di RSUP M.Djamil Padang selama tahun 2012 tercatat sebanyal 125 kasus namun sampel yang diambil hanya sebanyak 52 kasus dengan melihat kelengkapan datadata yang ada dicatatan klien. Dengan meneliti data-data yang ada dicatatan medical record tersebut terlihat faktor faktor apa saja yang mempengaruhi kejadian abortus pada ibu tersebut. Dari faktor - faktor yang diteliti diantaranya : Pariatas, umur ibu, Pekerjaan ibu, Riwayat penyakit, Jarak kehamilan dan kadar $\mathrm{Hb}$ ibu dapat kita jelaskan sebagai berikut :

\section{Analisa Univariat}

a. Paritas

Dari Tabel 4.4 terlihat jumlah anak ( paritas ) ibu lebih banyak responden memiliki jumlah anak lebih dari 3 yakni : $59,6 \%$ ( 31 Orang ). Hal ini menunjukkan sebagian ibu sangat beresiko mengalami kejadian abortus.

Menurut Warburton dan Frases (1964), Wilson, et al (1996) menyampaikan bahwa resiko abortus meningkat dengan bertambahnya paritas ibu (Cuningham, 2005 : 951).

Paritas adalah jumlah anak seorang ibu melahirkan anak viabel. Paritas 2-3 orang anak merupakan paritas beresiko yang mempunyai dampak terhadap kematian maternal (Prawirohardjo dan Winkjosastro, 2007 : 305).

b. Umur Ibu

Dari Tabel 4.5 terlihat sebagian responden jika dilihat dari sisi umur yang menyebabkan abortus terdapat $57.7 \%$ ( 30 orang ). Artinya ibu-ibu yang mengalami abortus sebagian besar berada pada rentang umur yang kurang baik un tuk kehamilan.

Umur merupakan faktor resiko lain untuk terjadinya abortus. Umur yang dimaksud yaitu umur aman akan kehamilan dan pesalinan pada umur 20-35 tahun. Kematian pada wanita hamil dan melahirkan pada umur di bawah 20 tahun yaitu 2-5 kali lebih tinggi dari umur 20-29 tahun dan meningkat lagi sesudah berudah berumur 30-35 tahun (Prawirohardjo dan Winkjosastro, 2007 : 315).

\section{c. Pekerjaan Ibu}

Dari Tabel 4.6 terlihat pada umumnya responden tidak bekerja yakni $84,6 \%$ (44 orang). Hal ini akan menurunkan resiko abortus mengingat ibu sebagian besar hanya melakukan pekerjaan sehari-hari sebagi ibu rumah tangga.

Pekerjaan yang dimaksudkan disini adalah pekerjaan berat yang dilakukan 
oleh ibu hamil sehingga ibu mesti mengeluarkan tenaga ekstra untuk melakukan pekerjaan tersebut atau dengan adanya emansipasi wanita pada zaman sekarang ini, maka kondisi wanita atau ibu yang bekerja banyak kita jumpai di bidang apa saja. Kondisi ini juga terjadi pada ibu hamil yang bekerja, Di Indonesia belum ada Undang-undang yang mengatur ibu hamil untuk tidak bekerta atau mendapatkan cuti selama hamil, sehingga kondisi ini dapat memicu angka kejadian abortus pada ibu hamil yang bekerja pada bidang pekerjaan yang membutuhkan tenaga atau fisik yang stabil.

\section{d. Riwayat Penyakit}

Dari Tabel 4.7 terlihat sebagian besar responden tidak ada menderita penyakit pada waktu kejadian abortus. Hal ini menunjukkan bahwa penyakit bukan sebagai faktor yang berkontribusi untuk kejadian abortus yang dialami ibi saat ini baik ibu yang mengalami abortus satu kali ataupun ibu yang mengalami abortus lebih dari satu kali.

Walaupun faktor penyakit tidak memberikan kontribusi pada kejadian abortus namun perlu di lihat dan diperhatikan faktor-faktor lain yang lebih memungkinkan abortus yang dialami ibu sangat dominan .

\section{e. Jarak Kehamilan Sebelumnya}

Dari Tabel 4.8 terlihat sebagian responden jarak kehamilannya tidak beresiko dalam penyebab abortus yakni $57.7 \%$ ( 30 orang ).

Menurut WHO jarak yang baik antara kehamilan yang laiu dengan kehamilan berikutnya adalah antara $2-5$ tahun. Maconochie,dkk mengatakan bahwa jaeak kehamilan yang terlalu lama akan meningkatkan terjadinya abortus dan sebaliknya jarak yang terlalu dekan akan meningkatkan juga kejadian abortus.

\section{f. Kadar $\mathrm{Hb}$}

Dari Tabel 4.10 terlihat responden yang mengalami kejadian abortus lebih dari 1 kali hanya $15.4 \%$ ( 8 orang )

Kehamilan secara fisiologis akan berpengaruh pada kadar Haemoglobin ibu akibat terjadinya peningkatan volume darah selama proses kehamilan. Sehingga kadar $\mathrm{Hb}$ yang rendah masih banyak dijumpai pada ibu hamil, ditambah lagi jika ibu selama hamil mengalami asupan gizi yang kurang. Hal ini akan meningkatkan kejadian abortus pada ibu hamil.

\section{Analisa Bivariat}

Dari hasil penelitian yang telah dilakukan pada 52 orang responden yang mengalami abortus di RSUP Dr. M.Djamil Padang selama tahun 2012 dengan memperhatikan kriteria inklusi dan ekslusi dan setelah dilakukan uji chi-Square dengan derjat kemaknaan $\alpha=0,05$, maka dari keseluruhan faktor-faktor resiko yang peneliti amati diantaranya : Faktor Paritas, Faktor Umur, Faktor Pekerjaan, Faktor Riwayat penyakit yang pernah diderita ibu, Faktor kadar $\mathrm{Hb}$ dan faktor jarak kehamilan dengan yang sebelumnya didapatkan hasil bahwa : faktor pekerjaan dan kadar $\mathrm{Hb}$ menunjukkan hasil yang bermakna yakni untuk faktor pekerjaan $\mathrm{p}=$ 0,000 sedangkan untuk faktor kadar $\mathrm{Hb} \mathrm{p}=$ 0,001. Jika di bandingkan dengan kemaknaan kedua faktor tersebut sangat signifikan.

Faktor pekerjaan menunjukkan hasil yang signifikan tapi bertolak belakang dengan persepsi ibu tentang faktor pekerjaan, hampir sebagian besar ibu mengatakan tidak berkerja atau hanya sebagai ibu rumah tangga. Hal ini sangat kita kuatirkan dimana jika dilihat pekerjaan ibu rumah tangga pada masingmasing responden tidak bisa dinilai berat atau ringannya pekerjaan yang dilakoni 
ibu. Namun persepsi pekerjaan ibu rumah tangga merupakan pekerjaan yang ringan dan bekerja diluar merupakan pekerjaan yang berat merupakan pandangan yang sangat keliru dan perlu upaya untuk menentukan standar berat ringan pekerjaan dengan mengukur aktifitas ibu masingmasing.

Faktor kadar $\mathrm{Hb}$ ibu juga menunjukkan hasil yang signifikan dimana kadar haemoglobin yang rendah akan meningkatkan insiden abortus. Hal ini sejalan dengan penelitian abidin.Z, $2011 \mathrm{di}$ RS, Kariadi Semarang dimana dikatakan kadar $\mathrm{Hb}$ ibu yang rendah akan menyebabkan angka kejadian abortus meningkat.

Fungsi $\mathrm{Hb}$ sangat vital sekali didalam tubuh,. $\mathrm{Hb}$ berperan sebagai alat transportasi $\mathrm{O} 2$ serta nutrisi ke seluruh jaringan tubuh. Jika kadarnya kurang didalam tubuh sehingga transportasi $\mathrm{O} 2$ dan nutrisi juga akan terganggu dan kondisi anemia sangat banyak ditemui pada ibu hamil. Secara fisiologis kehamilan akan menyebabkan peningkatan volume darah yang seharusnya didiringi oleh peningkatan sel-sel darahnya. Pada kondisi anemia akan mudah terlepasnya hasil konsepsi dari uterus, sehingga pengaturan zat-zat gizi pada ibu hamil penting sekali diperhatikan oleh ibu maupun atas dukungan keluarga agar bayi dan ibu dapat sehat sampai pada masa kelahirannya.

Menurut pendapat Ebrahim.dkk anemia selama kehamilan dapat menyebabkan terjadinya berat badan lahir rendah, prematuritas, cacat mental bahkan kematian pada perinatal. Ibu hamil yang mengalami anemia memiliki resiko yang lebih tingga untuk mengalami abortus.

Namun faktor-faktor lain seperti : umur ibu, Paritas, Riwayat penyakit yang diderita ibu serta faktor jarak tidak menunjukkan hasil yang signifikan. Hal ini sangat berbeda sekali dengan penelitian- penelitian sebelumnya, diantaranya penelitian

\section{KESIMPULAN DAN SARAN}

Pada penelitian ini ingin mengetahui faktor - faktor resiko kejadian abortus di RSUP Dr. M.Djamil Padang tahun 2012 dengan jumlah populasi sebanyak 125 responden dan sampel sebanyak 52 responden dapat diambil kesimpulan sebagai berikut:

1. Distribusi frekwensi kejadian abortus yang mengalami lebih satu kali sebanyak $15,4 \quad \% \quad(8$ orang ) sedangkan yang mengalami abortus satu kali sebanyak $84,6 \quad \% \quad(44$ orang).

2. Distribusi frekwensi kejadian abortus berdasarkan umur ibu yang merupakan penyebab abortus sebanyak 42,3\% ( 22 orang ) sedangkan yang tidak penyebab 57,7 $\%$ (30 orang).

3. Distribusi frekwensi kejadian abortus berdasarkan paritas yang merupakan penyebab sebanyak 59,6 \% ( 31 orang ) dan yang bukan penyebab sebanyak 40,4\% ( 21 orang )

4. Distribusi frekwensi kejadian abortus berdasarkan pekerjaan ibu yang bekerja sebanyak $15,4 \%$ ( 8 orang ) sedangkan ibu yang tidak bekerja sebanyak $57,7 \%$ (30 orang).

5. Distrubusi frekwensi kejadian abortus berdasarkan kadar $\mathrm{Hb}$ yang memiliki kadar $\mathrm{Hb}$ rendah sebanyak $21,2 \%$ (11 orang) sedangkan kadar $\mathrm{Hb}$ yang normal sebanyak $78,8 \%$ ( 41 orang ).

6. Distribusi frekwensi kejadian abortus berdasarkan riwayat penyakit ibu yang pernah menderita suatu penyakit sebanyak 1,9\% ( 1 orang ) sedangkan yang tidak pernah menderita suatu penyakit sebanyak $98,1 \%$ ( 51 orang )

7. Distribusi frekwensi kejadian abortus dengan jarak kehamilan sebelumnya 
yang memiliki resiko sebanyak 42,3 $\%$ ( 22 Orang ) dan yang tidak beresiko sebanyak 57,7 \% (30 orang)

8. Tidak ada hubungan umur ibu dengan kejadian abortus dengan nilai $\mathrm{p}=1,000>\alpha 0,05$.

9. Tidak ada hubungan paritas dengan kejadian abortus dengan nilai $\mathrm{p}=0,700>\alpha 0,05$.

10. Terdapat hubungan pekerjaan ibu dengan kajadian abortus dengan nilai $\mathrm{p}=0,000<\alpha 0,05$.

11. Terdapat hubungan kadar $\mathrm{Hb}$ dengan kejadian abortus dimana nilai $\mathrm{p}=0,001<\alpha 0,05$

12. Tidak ada hubungan riwayat penyakit dengan kejadian abortus dengan nilai $\mathrm{p}=1,000<\alpha 0,05$

13. Tidak ada hubungan jarak kehamilan dengan kejadian abortus dengan nilai $\mathrm{p}=0,260<\alpha 0,05$

Setelah melihat kesimpulan yang didapat dari hasil penelitian diatas maka pada kesempatan ini dapat kami sarankan sebagai berikut :

1. Bagi Institusi Pelayanan

Kelengkapan data dalam catatan medik klien sangat penting diperhatikan bagi pihak rumah sakit dengan selalu melakukan fungsi pengawasan bagi petugas di ruangan sehingga pada saat klien pulang dari rumah sakit data-data penting yang berhubungan dengan penyakit klien dapat dilengkapi sebelum diberikan status ke petugas medical record.

2. Bagi Instansi Pendidikan

Diharapkan dengan adanya penelitian ini akan dapat menambah informasi pada perpustakaan pendidikan sehingga dapat diakses oleh mahasiswa yang membutuhkan khusnya dalam mata kuliah keperawatan maternitas.

3. Bagi Peneliti selanjutnya

Mengingat belum dapatnya dijelaskan penyebab abortus pada ibu dan masih banyak perbedaan yang didapatkan pada penelitian-penelitian sebelumnya tentang faktor resiko kejadian abortus di lapangan maka perlu terus dilakukan penelitian tentang faktor-faktor resiko kejadian abortus dengan metode yang berbeda.

\section{DAFTAR PUSTAKA}

Arikunto.S. ( 2002 ). Prosedur Penelitian Edisi Revisi V. Jakarta:Rineka Cipta

Budiarto. Eko. ( 2003 ). Metodologi Penelitian Kedokteran.Bandung: EGC

Cunninghan,F. ( 1995 ). Obstetri Williwm. Alih Bahasa. Edisi 18. Jakarta: EGC

http://Indah. Jarak Kehamilan Yang aman, www.Depkes.co.id 12-5-2008

http://Joeharno. 2008. Beberapa Faktor Resiko Kejadian BBLR.

Joe.com@yahoo.com

Manuaba.IBG.1998. Ilmu Kebidanan

Penyakit Kandungan dan Keluarga

Berencana.Jakarta:EGC.

Mochtar. R. 1998. Sinopsis Obstetri . Jilid I.Jakarta :EGC

Notoadmojo.S. ( 2003 ).Metode Penelitian . Jakarta: Rineka Cipta

Sarwono. ( 2002 ) Ilmu Kebidanan. YBPSP. Jakrta: EGC

Saefuddin. 2002. Buku Panduan Praktis

Pelayanan Kesehatan Maternal dan Neonatal. Jakarta:YBP-SP

Sartrawinata. S. ( 2005 ). Obtetri Patologi. Bandung: EGC

Varney. H. 1998. Ilmu Kebidanan, Jilid I. Jakarta: EGC 